\title{
Monica Heller (ed): Bilingualism: A Social Approach (Palgrave Advances in Linguistics)
}

\author{
Palgrave Macmillan, Basingstoke, 2007, 384 pp, Pb £19.99, \\ ISBN 9781403996787
}

\section{Beatrice Fracchiolla}

Received: 30 August 2008/Accepted: 1 September 2008/Published online: 1 October 2008 (C) Springer Science+Business Media B.V. 2008

Bilingualism: A Social Approach is a difficult book to present shortly. It opens with a summary of bilingualism around the world adopting a sociolinguistic approach, including contributions by twenty different international authors who describe and analyse such situations with the idea that language is connected to society and culture and is a form of social practice. Thus, questions of citizenship, language, competition among institutions, groups and individuals and their relationship to the state are explored according to different historical and geographical contexts such as colonialism, neo-colonialism, migration, but also other social organisations, such as those of a religious nature.

In her introduction on "bilingualism as ideology and practice", Heller gives the theoretical framework needed to understand the perspectives of the contributors, which are based on historical and sociolinguistic approaches or, as she says, set "within specific discursive regimes" (p. 1), to use Foucauldian language. The purpose of the book is to understand the meanings of bilingualism today, through a variety of contributions reflecting today's social changes and "how new understandings of it, as ideology and practice, also contribute to linguistic and social theory" (p. 1). Divided into four parts, the book starts with a first part on "Bilingualism, Nation, State and Capitalism", articulating bilingualism with ideologies of state and nation from the nineteenth century to nowadays. Stroud explores the idea of bilingualism through colonialism and postcolonialism as a social construct, especially in Mozambique. Jaffe treats bilingual practices and linguistic ideologies and attitudes concerning bilingualism in the minority language context on the French island of Corsica. Pujolar examines bilingualism in the postnational era: how it is rooted in the nation-state as defined in the eighteenth century and during the French Revolution, and how the new economy involves language in new ways. Muehlman and Duchêne show how nation-states no longer have the

B. Fracchiolla $(\bowtie)$

Université de Paris 8, Paris, France

e-mail: bearfrac@yahoo.com 
political monopoly over their cultural policies while examining international agencies such as the United Nations as new sites of discourses on bilingualism. Patrick's contribution closes on language endangerment and language rights.

The second part then explores the analysis of institutional discourse. Nowadays, the mobility of persons across state borders is neither a unique experience in time nor a limited one, Moyer and Martin Rojo remark. Studying data from the sites of a health clinic in the Catalan-Spanish bilingual city of Barcelona and a Spanish secondary school in Madrid leads them to consider bilingualism as a challenge that goes with the evolution of migration and citizenship as well as globalisation. Martin-Jones looks at the role of education in a variety of contexts. She aims at making the case for conducting critical research on language in education in bilingual and multilingual settings, also considering discourses on what counts as a 'legitimate' language and creating monolingual spaces for learning (p. 163).

Da Silva, McLaughlin and Richards wonder about linguistic and cultural performances and legitimacy and their forms in the new economy, through data and examples from the call centre industry and from tourism development strategies in francophone Ontario. What are 'good' Francophone, French and bilingual practices? Who defines the 'true' identity of the speaker? Why and how? What are the consequences? Are skills and performances neutral or are they necessarily contextualised? They notice that a number of discursive tensions concern access to symbolic and material resources, and revolve around the question of authenticity.

Androutsopoulos' very rich chapter focuses on the question of bilingualism in the mass media and on the Internet. Especially interesting is his reflexion on the use of non-native English and the styling of 'glocal' identities (p. 222) and how this problematic eventually "reinforces a dissociation of language and nation, as counter-normative uses of non-native English construct imagined alliances with global cultural movements and may well be used to challenge the hegemony of English-speaking countries" (p. 225).

In the third part, "Identity Practices", Garett explores language socialisation and the (re)production of bilingual subjectivities in a St Lucian community and thus the relationship between English and Kwéyòl. In his chapter on heteroglossia and boundaries and the processes of linguistic distinction, Bailey focuses on the negotiation of identity through bilingualism presented as a popular and analytical category of social construct.

The fourth and final part argues that a close examination of linguistic practice requires rethinking our ideas about language as an autonomous system. Tsitsipis examines bilingualism as a social praxis with a focus on a receding language of modern Greece: Arvanitika. He points out the importance of studying power and symbolic domination and of making more explicit "how conceptualizations of bilingualism are locally formed through the structuring power of deskilling, reskilling and empowerment" (p. 293).

Mondada's contribution is peculiar in presenting code switching in a context of talk in workplaces where English is officially used as the lingua franca together with French as a resource for the organisation of action and interaction. And that it is not "the manifestation of bilingual identities but an endogenous flexible resource for constituting the interactional order" (p. 315). Auer expands on why bilingual talk is 
still a challenge for linguistics, while attempting to look at the boundaries of talk in one language code: where does one language stop and the other one start in bilingual talk? Does code-switching belong to grammar or performance? He concludes that languages used in bilingual talk are not the same languages that are used in monolingual talk.

In a final chapter, Heller proposes new perspectives of research on bilingualism mainly the relationship between ideologies and language, the relationship with social theory and what it means for research methods. Finally, a postface by Tabouret-Keller in French summarises all the issues which have emerged from the book, concluding on the fact that "un vaste chantier est en cours, qui concerne l'articulation entre les dimensions sociales du bilinguisme et sa portée culturelle" ("a large field of research is in progress, concerning the link between the social dimensions of bilingualism and its cultural impact") (p. 355).

On the whole, the book offers interesting perspectives on bilingualism and its place in history and modern society. It therefore serves as a reference for understanding new perspectives and bilingualism itself as an ideological product.

\section{Author Biography}

Beatrice Fracchiolla is Assistant Professor at the University of Paris 8 in language sciences where she teaches French as a Foreign Language. Her research interests are in political discourse analysis, intercultural studies and anthropology of communication and her publications include a variety of articles on all those fields (for more information on her work and research, see http://bearfrac.free.fr). She is also part of the MSH Paris Nord, and SYLED research group at University of Paris 3. 